\title{
PENGGUNAAN BERBAGAI KOMPOSISI MEDIA TANAM \\ DAN KONSENTRASI PUPUK ORGANIK HAYATI \\ TERHADAP PERTUMBUHAN DAN PRODUKSI \\ BAWANG MERAH VARIETAS BIMA \\ (Allium ascalonicum L.)
}

\author{
Ambo Upe \\ Fakultas Pertanian Universitas Puangrimaggalatung Sengkang \\ e-mail: amboupestip1969@gmail.com
}

\begin{abstract}
Ringkasan
Penelitian bertujuan untuk mengetahui pengaruh penggunaan berbagai komposisi media dan konsentrasi pupuk organik hayati $(\mathrm{POH})$ terhadap pertumbuhan dan produksi bawang merah varietas Bima. Penelitian dilaksanakan dalam bentuk rancangan acak kelompok (RAK) dengan pola factorial dua factor. Faktor pertama komposisi media terdiri dari media 1;1;1 (tanah, sekam padi, dan kotoran sapi), media 1;2;1 (tanah, sekam padi dan kotoran sapi) dan media 1;1;2 (tanah, sekam padi dan kotoran sapi). Faktor kedua adalah konsentrasi POH terdiri dari Tanpa POH, POH 10 ml/liter air, dan $\mathrm{POH} 30 \mathrm{ml} / \mathrm{liter}$ air. Hasil analisis data menunjukkan bahwa: Perlakuan berbagai komposisi media tanam terhadap pertumbuhan dan produksi tanaman bawang merah terbaik pada perlakuan media 1;1;2 (tanah, sekam padi dan kotoran sapi). dengan rata-rata bobot 145,67 gram/tanaman dan perlakuan berbagai konsentrasi $\mathrm{POH}$ terhadap pertumbuhan dan produksi tanaman bawang merah terbaik pada perlakuan POH $10 \mathrm{ml} /$ liter air dengan rata-rata bobot 113,00 gram/tanaman. Sedangkan interaksi antara komposisi media tanam dengan konsentrasi POH terhadap pertumbuhan dan produksi tanaman bawang merah terbaik pada perlakuan media 1;1;2 (tanah, sekam padi dan kotoran sapi) dengan Tanpa $\mathrm{POH}$, dengan rata-rata bobot 153,33 gram/tanaman.
\end{abstract}

Kata kunci: komposisi media, konsentrasi POH, bawang merah. 


\title{
Use of Various Composition of Plant Media and Concentration of Bio Organic Fertilizer (POH) Toward Growth and Production Bima Shallots Varieties (Allium ascalonicum L.)
}

\begin{abstract}
The study aims to determine the effect of the use of various media compositions and concentrations of organic organic fertilizer $(\mathrm{POH})$ on the growth and production of Bima varieties of shallots. The study was conducted in the form of a randomized block design (RBD) with a two factor factorial pattern. The first factor of media composition consisted of media 1; 1; 1 (soil, rice husk and cow dung), media 1; 2; 1 (soil, rice husk and cow dung) and media 1, 1; 2 (soil, rice husk) and cow dung). The second factor is the concentration of $\mathrm{POH}$ consisting of $\mathrm{NO} \mathrm{POH}, \mathrm{POH} 10 \mathrm{ml} /$ liter of water, and $\mathrm{POH} 30 \mathrm{ml} /$ liter of water. The results of the data analysis showed that: The treatment of various composition of the planting media to the growth and production of the best onion plants in the media treatment 1, 1; 2 (soil, rice husk and cow dung). with an average weight of 145.67 grams / plant and the treatment of various concentrations of $\mathrm{POH}$ on the growth and production of the best shallot plants in the treatment of $10 \mathrm{ml} /$ liter $\mathrm{POH}$ with an average weight of 113.00 grams / plant. While the interaction between the composition of the planting media with the concentration of $\mathrm{POH}$ on growth and production of the best shallot plants in the media treatment 1, 1, 2 (soil, rice husk and cow dung) with no POH, with an average weight of 153.33 grams / plant.
\end{abstract}

Keywords: media composition, POH concentration, shallots.

\section{PENDAHULUAN}

Bawang merah (Allium ascalonicum L) merupakan salah satu komoditas tanaman hortikultura yang banyak dikonsumsi manusia sebagai campuran bumbu masak setelah cabe (Suriani, 2012). Bawang merah dapat tumbuh dan berproduksi dengan baik di dataran rendah sampai dataran tinggi, yaitu pada ketinggian 0-1000 m dpl. Meskipun demikian ketinggian optimalnya adalah 10-30 m dpl saja. Pada ketinggian 500-1000 m dpl, juga dapat tumbuh, namun pada ketinggian itu yang berarti suhunya rendah pertumbuhan tanaman terhambat dan umbinya kurang baik. Untuk pertumbuhannya tanaman bawang merah dapat tumbuh baik pada suhu antara $25-32^{\circ} \mathrm{C}$ dengan iklim kering serta suhu ratarata tahunannya $30^{\circ} \mathrm{C}$. Bila suhu di atas $32^{\circ} \mathrm{C}$ maka air tanah cepat menguap sehingga mengganggu penyerapan unsur hara oleh akar tanaman (Wibowo, 2007). Pada dataran tinggi, umur bawang merah dapat menjadi lebih panjang antara 15-30 hari (Sunarjono dan Soedomo, 1989).

Produksi bawang merah tahun 2014 sebesar 1,234 juta ton. Dibanding dengan tahun 2013, produksi meningkat sebesar 223.33 ribu ton (22.0\%) (BPS, 2015). Konsumsi bawang merah di Indonesia 4,56 kg kapita ${ }^{-1}$ tahun $^{-1}$ atau $0,38 \mathrm{~kg} \mathrm{kapita}^{-1}$ bulan $^{-1}$ dan mengalami kenaikan sebesar 10\% hingga $20 \%$ menjelang hari-hari besar keagamaan. Perkiraan kebutuhan bawang merah tahun 2015 mencapai 1,195,235 ton yang terbagi kebutuhan konsumsi 952,335 ton; kebutuhan benih 102,900 ton; kebutuhan industri 40,000 ton dan kebutuhan ekspor 100,000 ton. Produktivitas bawang merah di Indonesia masih tergolong rendah dengan kisaran 9 ton ha $^{-1}$, sedangkan potensinya dapat mencapai 17 ton 
$\mathrm{ha}^{-1}$ (Ciptady, 2015). Sedangkan untuk Sulawesi Selatan menurut data statistik propinsi (BPS, 2016a), bahwa pertanaman dan luas panen tanaman bawang merah tahun 2015 mencapai 7.019 ha dengan produksi $698.886 \mathrm{kw}$ (69.889 ton) sementara di Kabupaten Wajo data luas pertanaman dan banyaknya produksi bawang merah belum mempunyai data yang tercantum pada buku Kabupaten Wajo dalam angka tahun 2015 (BPS, 2016b).

Pertanian organik mampu meningkatkan produktifitas bawang merah. Oleh karena itu, salah satu alternatif untuk meningkatkan produktifitas bawang merah yaitu dengan menggunakan pupuk organik cair yang mempunyai spesifikasi kandungan dari unsur-unsur hayati atau yang dikenal dengan Pupuk Organik Hayati (POH). Menurut Samad (2008) bahwa pupuk organik cair adalah larutan dari pembusukan bahan-bahan organik yang berasal dari sisa tanaman, dan kotoran hewan, yang kandungan unsur haranya lebih dari satu unsur. Permasalahn yang terkait tentang sumber hara tanaman, juga yang lebih penting adalah kondisi atau jenis tanah yang digunakan dalam proses budidya bawang merah. Untuk memenuhi standar tingkat kesuburan tanah terhadap tanaman, maka berbagai hal yang dapat dilakukan diantaranya penambahan bahan organic yang bersumber dari buangan sisa-sisa tanaman dan juga dari kotoran ternak.

Upaya untuk meningkatkan produksi tanaman bawang merah antara lain dengan perbaikan sistem budidaya misalnya pada media tanam. Tanah memberikan nutrisi bagi tanaman karena tanah mengandung mineral yang dibutuhkan tanaman. Penggunaan media tanam tanah secara terus menerus dapat menyebabkan berkurangnya kandungan mineral dalam tanah dan pemadatan tanah. Pemadatan tanah menyebabkan akar tanaman tidak dapat tumbuh secara optimal (Purwati, 2018). Bahan organik yang digunakan sebagai media tanam telah mengalami proses pelapukan atau dekomposisi oleh mikroorganisme pembentuk kompos. Penggunaan bahan organik yang berasal dari pupuk kandang sebagai media tanam mampu mengembalikan kesuburan tanah melalui perbaikan sifat-sifat tanah, baik sifat fisik, kimiawi, maupun biologis (Dalimoenthe, 2013).

Kandungan pupuk hayati adalah mikrooganisme yang memiliki peranan positif bagi tanaman. Kelompok mikroba yang sering digunakan adalah mikroba-mikroba yang menambat $\mathrm{N}$ dari udara, mikroba yang malarutkan hara (terutama $\mathrm{P}$ dan $\mathrm{K}$ ), mikrobamikroba yang merangsang pertumbuhan tanaman (Anonim, 2008 dalam Herman, 2014). Kelompok mikroba penambat $\mathrm{N}$ sudah dikenal dan digunakan sejak lama. Mikroba penambat $\mathrm{N}$ ada yang bersimbiosis dengan tanaman dan ada juga yang bebas (tidak bersimbiosis). Contoh mikroba yang bersimbiosis dengan tanaman antara lain adalah Rhizobium sp Sedangkan clontoh mikroba penambat N yang tidak bersimbiosis adalah Azosprillium sp dan Azotobacter sp. (Anonim, 2008 dalam Herman, 2014).

\section{METODE PENELITIAN}

Penelitian dilaksanakan di Green House Fakultas Pertanian Universitas Puangrimaggalatung Sengkang. Penelitian dilaksanakan dalam bentuk rancangan acak kelompok (RAK) dengan pola factorial dua factor. Faktor pertama komposisi media (M) terdiri dari: M1 adalah Komposisi Media 1;1;1 (tanah, sekam padi dan kotoran sapi), M2 adalah Komposisi Media 1;2;1 ( tanah, sekam padi dan kotoran sapi), dan M3 adalah Komposisi Media 1;1;2 (tanah, sekam padi dan kotoran sapi). Factor kedua adalah konsentrasi POH (P), terdidari: P0 adalah tanpa POH (control), P1 adalah POH $10 \mathrm{ml} / \mathrm{liter}$ air, dan $\mathrm{P} 2$ adalah $\mathrm{POH} 30 \mathrm{ml} /$ liter air. Setiap perlakuan terdapat dua unit tanaman, kemudian diulang sebanyak tiga kali, sehingga keseluruhan terdapat 54 unit tanaman. Parameter pengamatan terdiri dar[: Jumlah daun diamati pada saat tanaman berumur 50, 
hari setelah tanam dengan cara menghitung semua daun yang telah terbentuk pada tanaman sampel, Jumlah anakan dihitung pada saat tanaman berumur 50 hari setelah tanam dengan cara menghitung semua anakan yang telah terbentuk pada tanaman sampel, dan Bobot tanaman ditimbang secara keseluruhan pada saat penen. Pengolahan data hasil pengukuran di lapangan melalui Analysis of Variance (ANOVA), dan dilakukan Analisis Uji Beda Nyata Jujur (BNJ) pada taraf 5 \% (Gaspersz, 1991).

\section{HASIL DAN PEMBAHASAN}

\section{Hasil}

\section{Jumlah Daun}

Perlakuan berbagai komposisi media tanam memperlihatkan pengaruh sangat nyata, sedangkan konsentrasi $\mathrm{POH}$ dan interaksi antara komposis media tanam dengan konsentrasi $\mathrm{POH}$ memperlihatkan pengaruh tidak nyata terhadap jumlah daun tanaman bawang merah pada umur 50 hari setelah tanam. Hasil Uji BNJ menunjukkan bahwa penggunaan berbagai komposisi media tanam terhadap jumlah daun tanaman bawang merah memperlihatkan perbedaan nyata antara perlakuan M1 dengan M3, tetapi berbeda tidak nyata antara perlakuan M1 dengan M2, demikian juga perlakuan antara M2 dengan M3 menunjukkan perbedaan tidak nyata (Tabel 1).

Tabel 1. Rata-rata jumlah daun tanaman bawang merah pada umur 50 hari setelah tanam.

\begin{tabular}{|c|c|c|c|c|c|c|}
\hline \multirow{2}{*}{ Media Tanam } & \multicolumn{3}{|c|}{ POC } & \multirow{2}{*}{ Rata-Rata } & \multirow{2}{*}{ Hasil Uji } & \multirow{2}{*}{$\begin{array}{c}\text { NP-BNJ } \\
\text { Media Tanam }\end{array}$} \\
\hline & P0 & P1 & $\mathrm{P} 2$ & & & \\
\hline M1 & 9.33 & 11.83 & 14.17 & 11.78 & $\mathrm{~b}$ & \\
\hline M2 & 18.83 & 17.67 & 20.33 & 18.94 & $a b$ & 8.23 \\
\hline M3 & 22.67 & 22.33 & 21.00 & 22.00 & $\mathrm{a}$ & \\
\hline
\end{tabular}

Keterangan: Rata-rata yang diikuti oleh huruf yang sama berarti berbeda tidak nyata pada taraf $\alpha=0,05$

\section{Jumlah Anakan}

Perlakuan berbagai komposisi media tanam memperlihatkan pengaruh sangat nyata, sedangkan konsentrasi $\mathrm{POH}$ dan interaksi antara komposis media tanam dengan konsentrasi $\mathrm{POH}$ memperlihatkan pengaruh tidak nyata terhadap jumlah anakan tanaman bawang merah pada umur 50 hari setelah tanam. Hasil Uji BNJ menunjukkan bahwa penggunaan berbagai komposisi media tanam terhadap jumlah anakan tanaman bawang merah memperlihatkan perbedaan nyata antara perlakuan M1 dengan M3, tetapi berbeda tidak nyata antara perlakuan M1 dengan M2, demikian juga perlakuan antara M2 dengan M3 menunjukkan perbedaan tidak nyata (Tabel 2).

Tabel 2. Rata-rata jumlah anakan tanaman bawang merah pada umur 50 hari setelah tanam.

\begin{tabular}{|c|c|c|c|c|c|c|}
\hline \multirow{2}{*}{$\begin{array}{l}\text { Media } \\
\text { Tanam }\end{array}$} & \multicolumn{3}{|c|}{ POC } & \multirow{2}{*}{ Rata-Rata } & \multirow{2}{*}{ Hasil Uji } & \multirow{2}{*}{$\begin{array}{c}\text { NP-BNJ } \\
\text { Media Tanam }\end{array}$} \\
\hline & P0 & $\mathrm{P} 1$ & $\mathrm{P} 2$ & & & \\
\hline M1 & 3.17 & 3.5 & 3.5 & 3.39 & $\mathrm{~b}$ & \\
\hline M2 & 3.83 & 4 & 4.17 & 4.00 & $a b$ & 1.35 \\
\hline M3 & 4.83 & 5.33 & 5.33 & 5.16 & $\mathrm{a}$ & \\
\hline
\end{tabular}

Keterangan: Rata-rata yang diikuti oleh huruf yang sama berarti berbeda tidak nyata pada taraf $\alpha=0,05$ 


\section{Bobot Tanaman}

Perlakuan berbagai komposisi media tanam memperlihatkan pengaruh sangat nyata, sedangkan konsentrasi $\mathrm{POH}$ dan interaksi antara komposis media tanam dengan konsentrasi $\mathrm{POH}$ memperlihatkan pengaruh tidak nyata terhadap bobot tanaman bawang merah pada umur 50 hari setelah tanam. Hasil Uji BNJ menunjukkan bahwa penggunaan berbagai komposisi media tanam terhadap bobot tanaman bawang merah memperlihatkan perbedaan nyata antara perlakuan M1 dengan M2 dan M3, tetapi berbeda tidak nyata antara perlakuan M2 dengan M3 (Tabel 3).

Tabel 3. Rata-rata bobot tanaman bawang merah pada umur 50 hari setelah tanam.

\begin{tabular}{ccccccc}
\hline Media & \multicolumn{3}{c}{ POC } & Rata-Rata & Hasil Uji & $\begin{array}{c}\text { NP-BNJ } \\
\text { Media Tanam }\end{array}$ \\
\cline { 2 - 4 } Tanam & P0 & P1 & P2 & & & \\
M1 & 22 & 46.33 & 51 & 39.78 & $\mathrm{~b}$ & \\
M2 & 93.33 & 119.33 & 140.33 & 117.66 & $\mathrm{a}$ & 60.84 \\
M3 & 153.33 & 136 & 147.67 & 145.67 & $\mathrm{a}$ & \\
\hline
\end{tabular}

Keterangan : Rata-rata yang diikuti oleh huruf yang sama berarti berbeda tidak nyata pada taraf $\alpha=0,05$

\section{Pembahasan}

Perlakuan berbagai komposisi media tanam memperlihatkan pengaruh yang nyata terhadap semua parameter pengamatan. sedangkan perlakuan konsentrasi $\mathrm{POH}$ dan interaksi antara komposisi media dengan konsentrasi $\mathrm{POH}$ menunjukkan pengaruh yang tidak nyata, sehingga pengaruh perlakuan yang tidak nyata tidak dilakukan uji lanjutan dan perlakuan yang berpengaruh nyata dilakukan uji lanjutan BNJ $(0,05)$. Perolehan nilai rerata tertinggi pada perlakuan komposis media M2 diduga bahwa kondisi sifat fisik dan kimia pada media tersebut sesuai dengan kebutuhan tumbuh tanaman bawang merah. menurut Dalimoenthe (2013) bahan organik yang berasal dari pupuk kandang sebagai media tanam mampu mengembalikan kesuburan tanah melalui perbaikan sifat-sifat tanah, baik sifat fisik, kimiawi, maupun biologis. Artinya bahwa perbandingan komposisi media tanah, sekam padi dan kotoran ternak (1:1:2). Dengan komposisi tersebut diduga pula bahwa kotoran ternak yang diberikan mampu mencukupi kebutuhan hara tanaman bawang merah dan didukung oleh adanya sekam padi yang menjadikan media tanam lebih gembur.

Menurut Sudirja (2007) bahwa bawang merah tumbuh baik pada tanah subur, gembur dan banyak mengandung bahan organik. Selanjutnya menurut Aurum (2005) bahwa kombinasi yang tepat antara pupuk kandang dengan media tanam lain dapat mempengaruhi pertumbuhan tanaman karena selain sebagai media tanam, pupuk kandang mengandung unsur hara yang dibutuhkan tanaman sehingga dapat menyediakan unsur hara bagi tanaman.

Perlakuan konsentrasi $\mathrm{POH}$ dan interaksi komposisi media tanam dengan konsentrasi $\mathrm{POH}$ menunjukka pengaruh yang tidak nyata. namun berdasarkan nilai rata-rata pengamatan secara umum memperlihatkan perlakuan P2 yang lebih tinggi. Hal ini diduga bakwa konsentrasi yang diaplikasikan pada P2 ( $\mathrm{POH} 30 \mathrm{ml} / \mathrm{l}$ air) masih sesuai dengan kebutuhan tanaman, meskipun dianggap sama dengan perlakuan p1 ( $\mathrm{POH} 10 \mathrm{ml} / \mathrm{l}$ air). Peran konsentrasi $\mathrm{POH}$ dalam perlakuan ini diduga belum mampu berfungsi secara maksimal. Menurut Anonim, 2008 dalam Herman, (2014) bahwa kandungan pupuk hayati adalah mikrooganisme yang memiliki peranan positif bagi tanaman. Kelompok mikroba yang sering digunakan adalah mikroba-mikroba yang menambat $\mathrm{N}$ dari udara, mikroba yang malarutkan hara (terutama $\mathrm{P}$ dan $\mathrm{K}$ ), mikroba-mikroba yang merangsang pertumbuhan tanaman. 


\section{KESIMPULAN DAN SARAN}

\section{Kesimpulan}

Berdasarkan hasil analisis data dari rata-rata pengamatan dan pembahasan, maka dapat disimpulkan bahwa:

1. Perlakuan berbagai komposisi media tanam terhadap pertumbuhan dan produksi tanaman bawang merah terbaik pada perlakuan M3 dengan rata-rata bobot 145,67 gram/tanaman.

2. Perlakuan berbagai konsentrasi $\mathrm{POH}$ terhadap pertumbuhan dan produksi tanaman bawang merah terbaik pada perlakuan P2 dengan rata-rata bobot 113,00 gram/tanaman.

3. Perlakuan interaksi antara komposisi media tanam dengan konsentrasi POH terhadap pertumbuhan dan produksi tanaman bawang merah terbaik pada perlakuan P0 dengan rata-rata bobot 153,33 gram/tanaman.

\section{Saran}

Berdasarkan hasil yang diperoleh dalam penelitian ini, maka dapat disarankan bahwa untuk usahatani bawang merah sebaiknya menggunakan sekam padi sebagai pembenah tanah dan pupuk organik dari kotoran sapi sebagai penggembur dan sumber hara bagi tanaman.

\section{DAFTAR PUSTAKA}

Aurum, M. 2005. Pengaruh jenis media tanam dan pupuk kandang terhadap pertumbuhan setek sambang colok (Aerva sanguinolenta Blume.). (Skripsi). Institut Pertanian Bogor. Bogor.

BPS, 2015. Badan Pusat Statistik Republik Indonesia. Jakarta.

BPS, 2016a. Sulawesi Selatan Dalam Angka tahun2016, Badan Pusat Statistik. Makasar.

BPS, 2016b. Kabupaten Wajo Dalam Angka tahun2016, Badan Pusat Statistik. Sengkang.

Ciptady, M. A. 2015. Budidaya Bawang Merah. Penebar Swadaya. Jakarta.

Dalimoenthe, S.L. 2013. Pengaruh media tanam organik terhadap pertumbuhan dan perakaran pada fase awal benih teh di pembibitan. Jurnal Penelitian Teh dan Kina. Vol. 16 No. 1.

Gaspersz,.1991. Metode Perancangan Percobaan. Penerbit, CV. Armico, Bandung Indonesia.Herman, 2014. Pengaruh berbagai jumla aplikasi pupuk hayati Tadabur terhadap pertumbuhan dan produksi tanaman Kacang Panjang. Skripsi STIP Puangrimaggalatung Sengkang.

Purwati . E., 2018. Pengaruh Media Tanam Dan Pupuk Organik Cair Terhadap Pertumbuhan Dan Produksi Bawang Merah. Skripsi Jurusan Agroteknologi Universitas Lampung

Sudirja, 2007 Budidaya Bawang Putih, Bawang Merah, Bawang Bombay. Penebar Swadaya, Jakarta.

Sunarjono, H. dan Soedomo, P. 1989. Budidaya Bawang Merah. Penerbit Sinar Baru, Bandung.

Suriani, N. 2012. Budidaya Bawang Merah. Cahaya Atma Pustaka. Yogjakarta. 